\title{
Treatment of Leukemia with Large Doses of Methotrexate and Folinic Acid: Clinical-Biochemical Correlates
}

\author{
William M. Hryniuk and Joseph R. Bertino \\ From the Departments of Pharmacology and Medicine, Yale University School \\ of Medicine, New Haven, Connecticut 06510
}

A B S T R A C T Patients with acute leukemia were given repeated cycles consisting of infusions of methotrexate followed by "rescue" with folinic acid. Peripheral blood leukemic cells were harvested from patients before cyclical treatment, and the rates of incorporation of thymidine and of deoxyuridine into deoxyribonucleic acid (DNA) were measuared in vitro. There was no relationship between the pretreatment incorporation of either deoxynucleoside into DNA and the clinical response to therapy. Methotrexate suppressed deoxyuridine incorporation into DNA by the leukemic blasts in vitro, but the patients whose cells were most sensitive to this effect did not necessarily go into remission when treated.

Leukemic cells were sampled during methotrexate infusions and the deoxynucleoside incorporation rates were determined. Thymidine incorporation into DNA was variably affected. If, by the end of the first infusion, it remained elevated, remission rarely followed, whereas if it was below the pretreatment value, remission was much more likely. In all cases, deoxyuridine incorporation was suppressed during the infusion. The greatest suppression occurred in patients who went on to remission, but the suppression did not correlate with that expected from pretreatment in vitro tests unless due weight was given to the concomitant effects of the methotrexate therapy on thymidine incorporation.

Leukemic blasts surviving successive cycles of therapy became progressively more resistant to the suppressing effects of methotrexate in vitro. This resistance became

This work was presented in part at the Annual Meeting of The American Federation for Clinical Research at Atlantic City, 30 April 1967.

Dr. Hryniuk is a Fellow of the Leukemia Society of America and a recipient of the Gordon Bell Memorial Fellowship. His present address is the Manitoba Cancer Research Foundation, 700 Bannatyne Ave., Winnipeg, Manitoba, Canada. Dr. Bertino is an Associate Professor of Medicine and Pharmacology and a Career Development Awardee of the National Cancer Institute.

Received for publication 28 August 1968 and in revised form 1 June 1969. especially marked in the blasts of patients who did not go into remission.

During methotrexate infusions, inhibition of leukemic cell dihydrofolate reductase activity was greatest in blasts of patients whose disease subsequently remitted.

\section{INTRODUCTION}

During the chemotherapy of malignant disease, some drugs produce much greater benefit if given in large infrequent doses instead of in small frequent doses. After the two modes of therapy, this can amount to the difference between complete eradication of the tumor versus no appreciable antitumor effect. Most notable in this respect is the folate antagonist, methotrexate (MTX) (1-10). Evidently, some property of rapidly proliferating tumor cells renders them peculiarly susceptible to the lethal effects of large doses of MTX. In addition, the antidote to MTX, which is folinic acid or leucovorin, can in some circumstances rescue the host but not the tumor from MTX $(7,11-13)$.

We have given patients with acute leukemia infusions of large doses of MTX followed immediately by folinic acid "rescue" and have studied the biochemical responses to MTX of the (deoxyribonucleic acid) DNA-synthesizing leukemic cells in the blood both before and during therapy. By correlating the biochemical responses of these cells with the outcome of therapy, we are attempting to detect those properties of malignant cells which are associated with the greatest vulnerability to large doses of the antifolate. This may point the way to therapeutic maneuvers which would further improve therapy results with MTX and may also contribute to a better understanding of the mechanism of action of antimetabolites in general.

MTX is well suited for this type of study, since it is not significantly metabolized in humans (14), can be easily measured (15), and its action is fairly well understood (16). From Fig. 1, it can be seen that the conversion of deoxyuridylate (dUMP) to thymidylate (dTMP) 
requires methylene tetrahydrofolate $\left(\mathrm{hFH}_{4}\right)$ and that repletion of the pool of this folate is effected by dihydrofolate reductase (DHFR). MTX inhibits this enzyme, thus inhibiting synthesis of DNA since dUMP can no longer be methylated to dTMP $(17,18)$. This blockade is believed to be responsible for the cytotoxic effects of $\operatorname{MTX}(17,19)$.

Since cells can phosphorylate exogenous deoxyuridine (UdR) to dUMP and thymidine (TdR) to dTMP, both deoxynucleosides can join the main pathway via the salvage pathway. Hence, the incorporation of UdR and TdR into DNA may serve as an index of the rate of DNA synthesis. If dUMP conversion to dTMP were blocked, this would appear as inhibition of incorporation of tritiated UdR (UdR- ${ }^{8} \mathrm{H}$ ) into DNA, but according to Fig. 1, tritiated $\mathrm{TdR}\left(\mathrm{TdR}-{ }^{8} \mathrm{H}\right)$ should still be incorporated if the DNA-synthesizing system were otherwise unchanged by MTX. Normal or even enhanced incorporation of TdR- ${ }^{8} \mathrm{H}$ into DNA might occur (20). Folinic

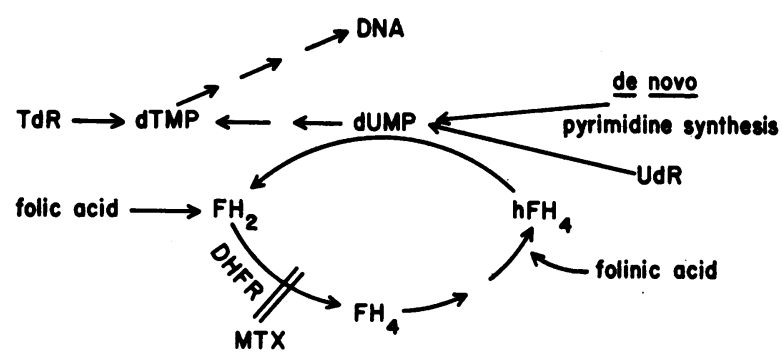

FIGURE 1 Methotrexate suppression of DNA synthesis by blockade of deoxyuridylate conversion. $\mathrm{FH}_{2}=$ dihydrofolate; DHFR = dihydrofolate reductase enzyme ; MTX $=$ methotrexate; $\mathrm{FH}_{4}=$ tetrahydrofolate; $\mathrm{hFH}_{4}=N^{5}, N^{10}$-methylene tetrahydrofolate; $\mathrm{dUMP}=$ deoxyuridylate; $\mathrm{dTMP}=$ thymidylate; $\mathrm{DNA}=$ deoxyribonucleic acid; $\mathrm{UdR}=$ deoxyuridine; $\mathrm{TdR}=$ thymidine.

acid ( $N^{5}$-formyltetrahydrofolic acid, leucovorin) should enable a cell to convert dUMP to dTMP even if MTX were present (21).

TABLE I

Patient Group Composition and Response to High Dose Methotrexate-Folinic Acid Therapy

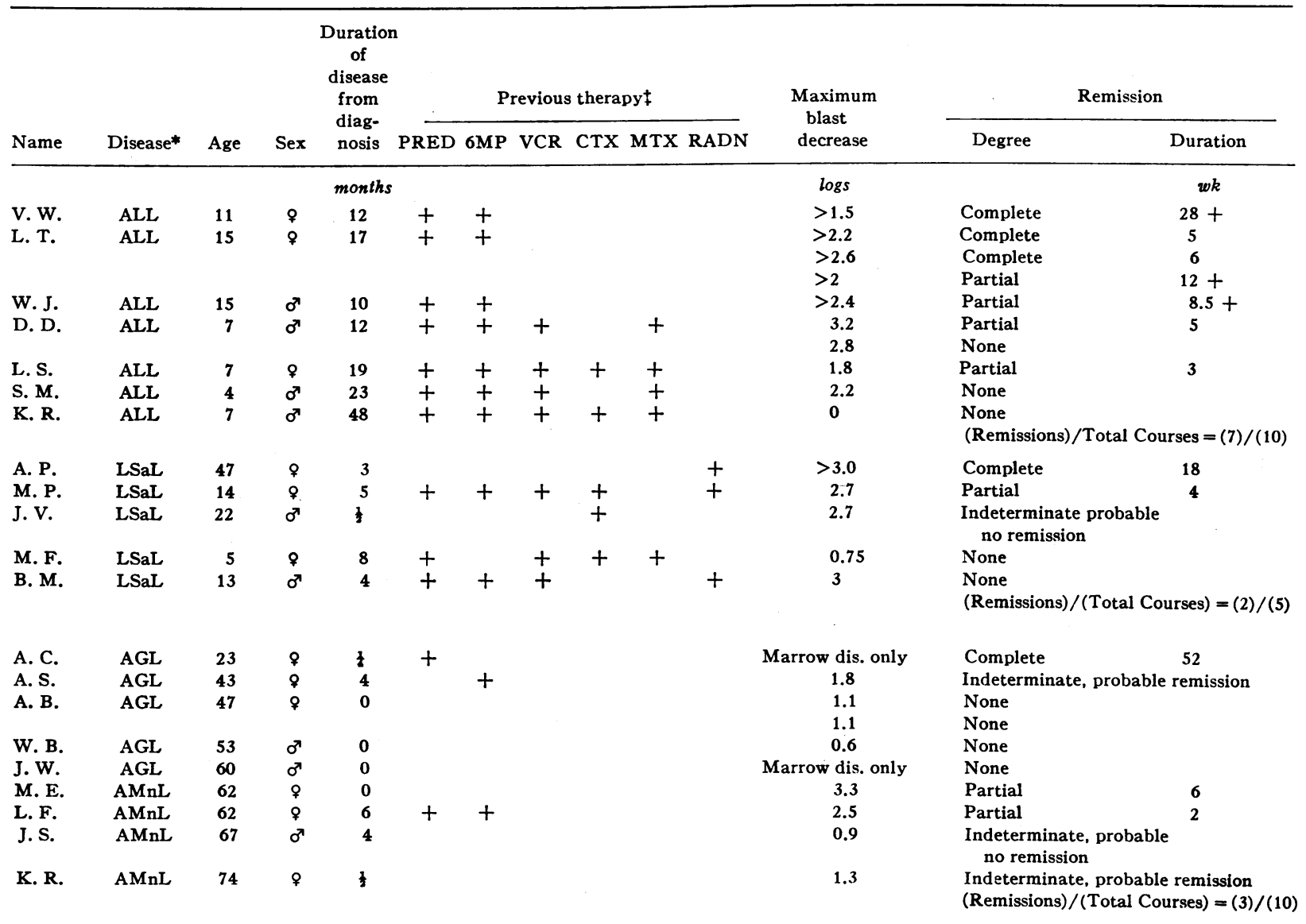

* ALL, acute lymphoblastic leukemia; AGL, acute granulocytic leukemia; AMnL, acute monocytic leukemia ; LSaL, lymphosarcoma cell leukemia. ¥PRED, prednisone; 6MP, 6-mercaptopurine; VCR, vincristine; CTX, cytoxan; MTX, methotrexate. repetitive low dose therapy; RADN, radiation 


\section{METHODS}

Patient population. The study group is described in Table I. Patients with acute lymphoblastic leukemia of childhood (ALL) and acute lymphosarcoma cell leukemia (LSaL) were combined as "lymphoblastic leukemia." Patients with ALL who had not been previously treated were not included in this study.

Therapy. MTX $\left(80,120\right.$, or $240 \mathrm{mg} / \mathrm{m}^{2}$ in $1000 \mathrm{ml}$ of $5 \%$ glucose in water) was infused intravenously over $24 \mathrm{hr}$. The higher doses were given to patients in whom pretreatment in vitro studies indicated these might be required. In all patients, folinic acid rescue was initiated immediately after termination of the MTX; 12-24 $\mathrm{mg}$ in four divided parenteral doses over the next $24 \mathrm{hr}$ was used initially but later $40-75 \mathrm{mg}$ was given intravenously over $6-12 \mathrm{hr}$ followed by $6 \mathrm{mg}$ orally every $6 \mathrm{hr}$ for four doses. Thus, a cycle of therapy consisted of one $24 \mathrm{hr}$ infusion of MTX followed by folinic acid for $24-36 \mathrm{hr}$ followed by a $1 \frac{1}{2}-3 \frac{1}{2}$ day rest period. A course of therapy consisted of repeated cycles of MTX-folinic acid until either a remission was induced, or therapy had to be stopped due either to neutropenia (neutrophil count below $200 / \mathrm{mm}^{8}$ ) or because the number of blasts no longer decreased with therapy. No other cytotoxic agents were used while remission was being induced. Platelet concentrates were used as necessary to keep the platelet count above $10,000 / \mathrm{mm}^{3}$.

Blood counts. Blood counts were usually done twice daily by routine hematological techniques. Absolute blast, neutrophil, and platelet counts were plotted on semilog paper versus the time elapsed from initiation of treatment. The error in

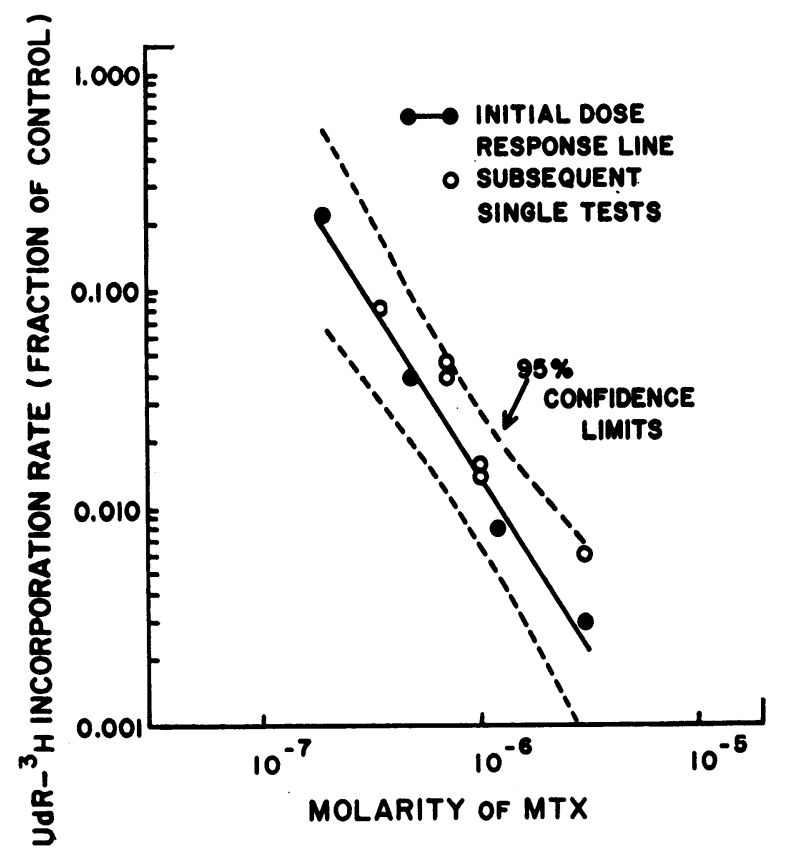

FIgURE 2 UdR- ${ }^{3} \mathrm{H}$ incorporation by blasts in the presence of MTX in vitro, reproducibility of drug effects. Cells from a patient with acute leukemia were tested in the week preceding therapy and rates expressed as fractions of the control rate. The dose-response line and its confidence limits were obtained on the first day, subsequent tests during the next 6 days. Control UdR- ${ }^{8} \mathrm{H}$ rates varied between 51 and 68 $\mathrm{cpm} / \mathrm{min}$ per $10^{\mathrm{B}}$ blasts. platelet counts was \pm 0.1 logs regardless of absolute value since counting dilutions were adjusted, but this was not done for blasts and neutrophils, and hence the error was \pm 0.2 logs at counts over $1000 / \mathrm{mm}^{8}$ and $\pm 0.3 \operatorname{logs}$ from $1000 / \mathrm{mm}^{8}$ to $50 / \mathrm{mm}^{3}$, the limit of detection. Decreases in counts from the pretreatment level to the nadir after therapy were expressed in logarithms. This method of expression allowed comparisons to be made of changes in counts regardless of their absolute values. However, if leukocyte counts fell below detection limits, the logs of decrease to $50 / \mathrm{mm}^{3}$ was measured and expressed as "greater than ( $>$ ) logs decrease." Thrombocytopenia and neutropenia due to MTX were defined as any decreases occurring in relation to MTX therapy other than changes due to infection or platelet transfusions.

Definition of remission. (a) Complete remission: normal blood counts and normal marrow ( $<5 \%$ leukemic cells); no hepatosplenomegaly.

(b) Partial remission : rise in platelet and neutrophil counts to normal or near normal values with more than a $90 \%$ $(1 \mathrm{log})$ reduction in peripheral blast count but with leukemic cells still detectable in blood or marrow.

(c) No remission: no rise in neutrophil or platelet count (regardless of change in blast content of blood or marrow).

(d) Indeterminate responses were classified in the no remission group.

When patients achieved remission, they were maintained with the MTX-folinic cycles at 4- to 14-day intervals and some received other drugs in addition. Thus, induction of remission but not duration of remission could be attributed solely to MTX therapy. When patients relapsed, all drugs were discontinued and the patients were restudied.

\section{Biochemical studies}

\section{Materials}

Thymidine-5-methyl ${ }^{3} \mathrm{H}$ (SA $1.9 \mathrm{mc} / \mu$ mole), deoxyuridine- $6-{ }^{3} \mathrm{H}$ (SA 1.33 and $3.2 \mathrm{mc} / \mu$ mole), ${ }^{1} \mathrm{MTX}$ (sodium salt), ${ }^{2}$ Eagle's basal medium with Earle's balanced salt solution, and bicarbonate buffer ( $\mathrm{pH} 7.1){ }^{3}$ horse serum," perchloric acid, 2,5-diphenyloxazole (PPO), $P$-bis [2-(5-phenyloxazolyl)]benzene (POPOP) absolute alcohol, toluene, the reduced form of triphosphopyridine nucleotide (NADPH), Tris buffer, $\mathrm{KCl}$, mercaptoethanol, and cetrimide ${ }^{5}$ were obtained commercially.

\section{METHODS}

The scintillation fluid mixture (22), dihydrofolic acid (23), cetrimide solution for counting leukocytes (24), and partially purified L1210 mouse leukemia DHFR ("Sephadex enzyme") (25), were prepared according to published methods. Preparation of leukemic cell extracts (26), measurement of DHFR activity at $\mathrm{pH} 7.0$ and 8.5 using dihydrofolate as the substrate (27), plasma MTX concentration determinations (15), ribonucleic acid (RNA) and DNA separations and measurements (28-30), and protein measurements (31), were performed according to published methods.

Separation of leukocytes. Leukocyte-rich plasma was decanted from heparinized venous blood after the erythrocytes had settled by gravity. A portion of the plasma was diluted

${ }^{1}$ Schwarz Bio Research Inc., Orangeburg, N. Y.

${ }^{2}$ American Cyanamid Co., Lederle Laboratories Div., Pearl River, N. Y.

${ }^{3}$ Microbiological Associates Inc., Bethesda, Md.

${ }^{4}$ Grand Island Biological Co., Grand Island, N. Y.

${ }^{5}$ Eastman Kodak Co., Eastman Organic Chemicals Div., Rochester, N. Y. 
TABLE II

Variation of Deoxynucleoside Incorporation Rate Determinations

\begin{tabular}{ccc}
\hline Samples compared & No. of tests & $\begin{array}{c}\text { No. with } \\
\text { difference } \\
\text { between } \\
\text { rates } \\
(P<0.05)\end{array}$ \\
\hline $\begin{array}{c}\text { Same blood sample } \\
\text { Duplicates } \\
30 \text { min vs. } 60 \text { min } \\
\text { incubation } \\
\text { Lysis of rbc } \\
\begin{array}{c}\text { Different blood samples } \\
\text { Same day }\end{array}\end{array}$ & 13 & 0 \\
\hline
\end{tabular}

into cetrimide and counted in a model B Coulter counter. The leukocytes were separated from the remainder of the plasma by centrifugation ( $1000 \mathrm{~g}$ for $4 \mathrm{~min}$ ) and resuspended in Eagle's medium containing $10 \%$ horse serum (EHS) to a cell density of from 1 to $11 \times 10^{6}$ leukocytes $/ \mathrm{ml}$. Erythrocytes were not removed by hypotonic state lysis, because this appeared to be unnecessary (unpublished observations). The percentage of blasts in the leukocyte suspension equaled that in whole blood and comprised $2-100 \%$ of the cells. Promyelocytes and myelocytes were included as blasts, but were rarely more than $5 \%$ of the proliferating cells in any suspension. Suspensions were prepared at room temperature, with $1.5-3$ hr elapsing from venipuncture to the beginning of the in vitro incubations.

Incubation of cell suspensions; measurement of deoxymucleoside incorporation rates. Several series of $10 \mathrm{ml}$ Erlenmeyer flasks were prepared, one series for each condition to be investigated. $1 \mathrm{ml}$ aliquots of cell suspension were added to each flask equilibrated with 5\% $\mathrm{CO}_{2}$. The flasks were stoppered and set into a shaking metabolic incubator at $37^{\circ} \mathrm{C}$. Later, deoxynucleoside was added to each flask, either $9 \times 10^{-4} \mu$ moles UdR- ${ }^{-5} \mathrm{H}$, or $6 \times 10^{-4} \mu$ moles $\mathrm{TdR}-{ }^{8} \mathrm{H}$. At intervals over the $30-45 \mathrm{~min}$ after addition of deoxynucleoside ice-cold 5\% perchloric acid (PCA) was added to a flask from each series. The precipitates that formed were washed free of acid-soluble radioactive compounds with $5 \% \mathrm{PCA}$, then hydrolyzed with $0.5 \mathrm{ml} 5 \%$ PCA by heating at $85^{\circ} \mathrm{C}$ for $15 \mathrm{~min}$. The radioactivity extracted from each precipitate was measured in a scintillation spectrometer with correction for efficiency of counting by external standardization. Counts were converted to a specific activity of 1.3 and $2.0 \mathrm{mc} / \mu$ mole for $U d R-{ }^{3} \mathrm{H}$ and $\mathrm{TdR}-{ }^{3} \mathrm{H}$, respectively.

The radioactivity thus measured in each sample was plotted against the time of incubation. A linear relationship was usually obtained from each series of flasks for the 1st $\mathrm{hr}$ of incubation. The slope of this line was calculated (32) and represented the rate of incorporation of deoxynucleoside into DNA. Results were expressed as counts per minute of incubation per million blasts in the suspension. The standard deviation of the slope was calculated (32), and rates not significantly different from zero (33) were not used in subsequent calculations.

Incubation conditions. (a) Rates in the absence of MTX. Each series of cells in suspension was preincubated without added antifolate and then deoxynucleoside was added and the

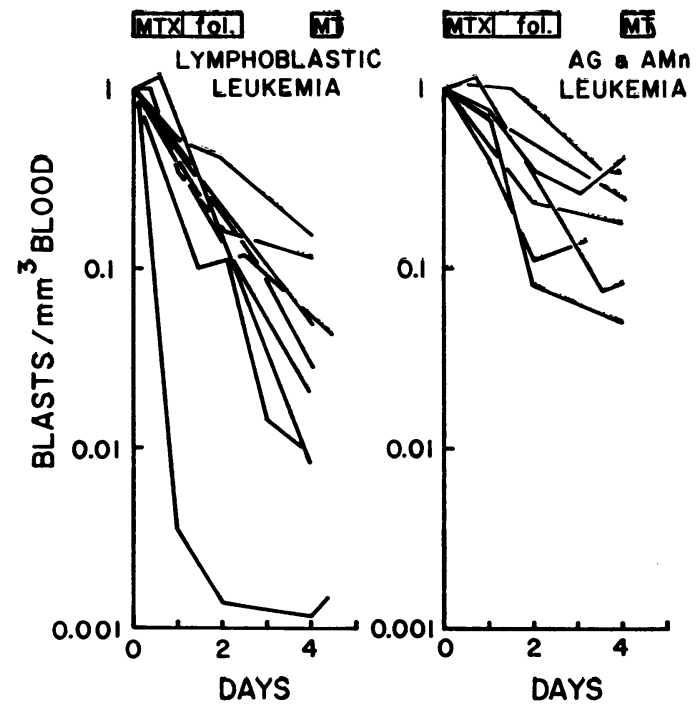

FIGURE 3 Changes in blast count during first therapy cycle. Blast counts are expressed as fractions of the pretreatment counts which varied between 0.5 and $130 \times 10^{\circ} / \mathrm{ml}$ blood $\left(500-130,000 / \mathrm{mm}^{3}\right)$. Patients had no previous exposure to high doses of MTX or folinic acid (fol.).

incorporation rate measured and expressed as described above. In addition, this "rate $/ 10^{\circ}$ blasts" was multiplied by the number of blasts, in millions, per milliliter of the original blood sample from which the cell suspension had been prepared and the rate thus calculated was termed "rate/milliliter of blood." "The cells harvested from patients during MTX infusions were preincubated for $10 \mathrm{~min}$, while the cells serving as controls for the in vitro sensitivity studies were preincubated for $30 \mathrm{~min}$ before deoxynucleoside was added.

(b) Rates in the presence of $M T X$ in vitro. Cells in suspension were preincubated with MTX at various concentrations (one series of flasks for each concentration) for $30 \mathrm{~min}$ at $37^{\circ} \mathrm{C}$, then deoxyuridine was added, and the rate of its incorporation into DNA measured as the rate/ $10^{\circ}$ blasts. This rate was divided by the control rate (see above), and the resulting quotient, expressed as a decimal fraction, was called the "fractional UdR incorporation rate." A fractional UdR incorporation rate was thus derived for each concentration of MTX tested. The fractional UdR rates were plotted against their respective MTX concentrations on double-log paper (Fig. 2) to give a dose-response relationship. No measurements were made of $T d R$ rates after exposure to MTX in vitro.

Reproducibility of $T d R$ and $U d R$ rates. Adjustments in cell concentration in the suspension and number of samples in each series allowed accurate measurements to be made of low incorporation rates. By thus keeping the error proportional to the absolute value of the rate, plotting the results on a logarithmic scale was justified (34). It was ascertained that $95-98 \%$ of the acid-insoluble counts (either from UdR or $\mathrm{TdR}$ ) were in the DNA fraction. The counts remaining

- Example: If the "rate $/ 10^{\circ}$ blasts" were $100 \mathrm{cpm} / \mathrm{min}$ and the original blood sample had contained 10,000 blasts $/ \mathrm{mm}^{3}$ $(10,000,000 \mathrm{blasts} / \mathrm{ml})$, then the "rate/milliliter blood" would have been $100 \times 10=1000 \mathrm{cpm} / \mathrm{min}$. 


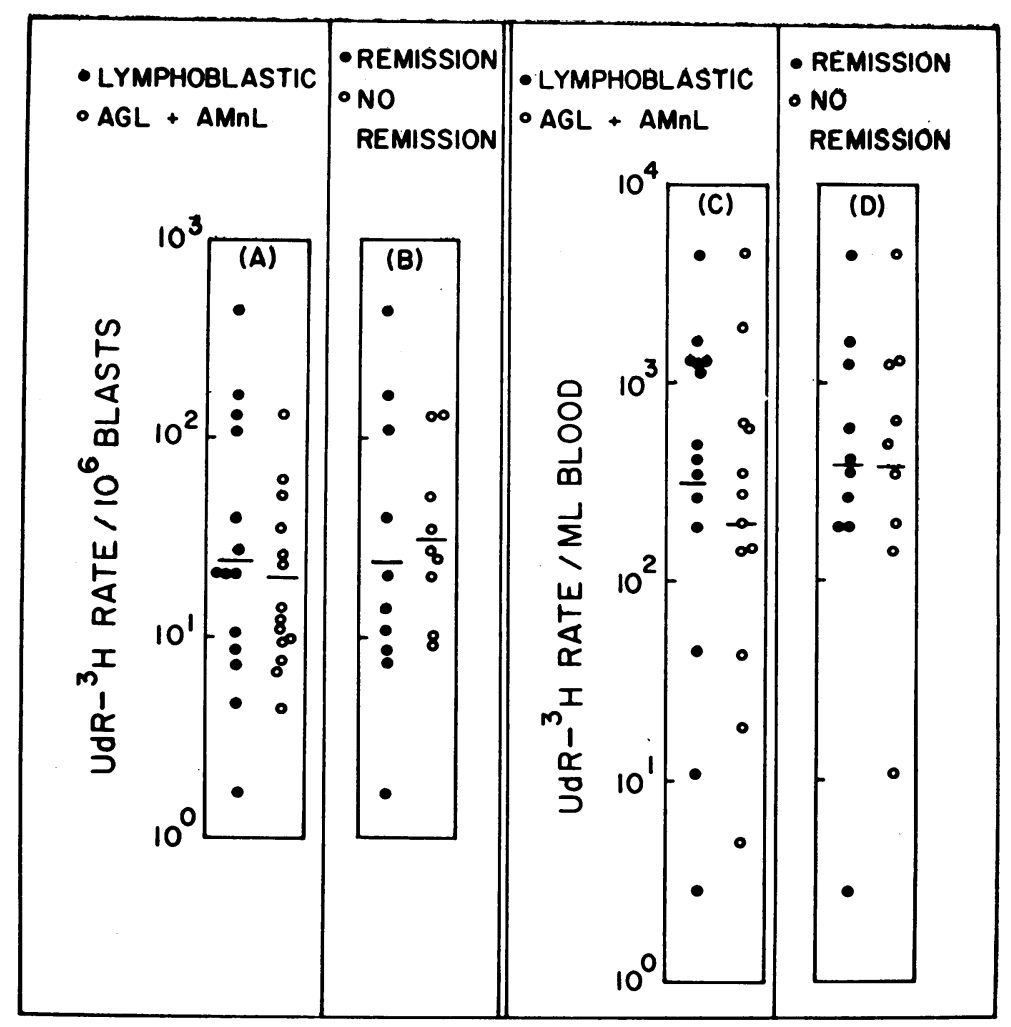

FIgURE 4 UdR- ${ }^{8} \mathrm{H}$ incorporation by blasts in the absence of MTX, comparison between cell types or response to treatment. Horizontal bars represent geometric means. Rates were measured in the absence of MTX and are expressed per $10^{\circ}$ blasts ( $\mathrm{A}$ and $\mathrm{B}$ ) or per blasts in $1 \mathrm{ml}$ of blood ( $C$ and $D)$. There were no significant differences between patient groups. Patients had no previous exposure to MTX-folinic therapy.

in the RNA fraction could be accounted for by contaminating DNA. Several potential sources of variation were checked and, as shown in Table II, results of rate determinations of the rate $/ 10^{\circ}$ blasts in the absence of MTX were quite reproducible on any one day. Since the results of these tests were the same for both $U d R$ and $T d R$, they are not distinguished in the table. These rates varied linearly with the concentration of blasts in the suspension up to $12 \times 10^{\circ} / \mathrm{ml}$, and the line relating incorporation rate to blast number went through the origin. This indicated that cells present in the suspension other than blasts did not incorporate label. Incubations lasting over $1 \mathrm{hr}$ frequently resulted in decreasing rates of label incorporation, and, therefore, total incubation time was kept to less than $1 \mathrm{hr}$.

Fig. 2 shows the fractional UdR rates in the presence of MTX in vitro of the leukemic cells of one patient as repeatedly determined in the week preceding institution of MTX therapy. Test results were quite reproducible since all fractional UdR rates fell within the $95 \%$ confidence limits of the dose-response line derived in the 1st day. In 24 of 25 such tests in 10 patients, the MTX sensitivity did not fluctuate significantly before therapy. The presence or absence of red cells did not appear to influence the sensitivity of blasts to MTX.

Rates measured during MTX therapy. Blood samples were drawn at approximately the 4th, 12th, and 24th hr of
MTX infusion and the 4th and 24th hr of folinic acid therapy. Cell suspensions were prepared as described above, and UdR and TdR incorporation rates were measured after only a $10 \mathrm{~min}$ preincubation period at $37^{\circ} \mathrm{C}$ (without MTX in the medium). The short preincubation period was chosen in an attempt to minimize efflux of intracellular drug.

Deoxynucleoside incorporation was thus measured during the drug infusions, and the rates were expressed both as per $10^{\circ}$ blasts in suspension and per milliliter of blood as explained above. These rates were expressed as decimal fractions of the respective preinfusion values.

Comparison of UdR rates during MTX therapy with those produced by in vitro MTX exposure. The plasma MTX concentration was measured in each blood sample drawn during drug infusions. A fractional UdR rate was predicted for this drug concentration by interpolating from the appropriate pretreatment dose-response line such as the one shown in Fig. 2. This fractional UdR rate was compared with that actually determined on the blasts from the blood sample. As will become apparent, there was frequently a great discrepancy between the predicted and the observed fractional UdR rates derived in this way. We therefore calculated a correction factor which, when applied to the observed fractional UdR rate, produced good agreement between the predicted and the observed fractional UdR rates. 


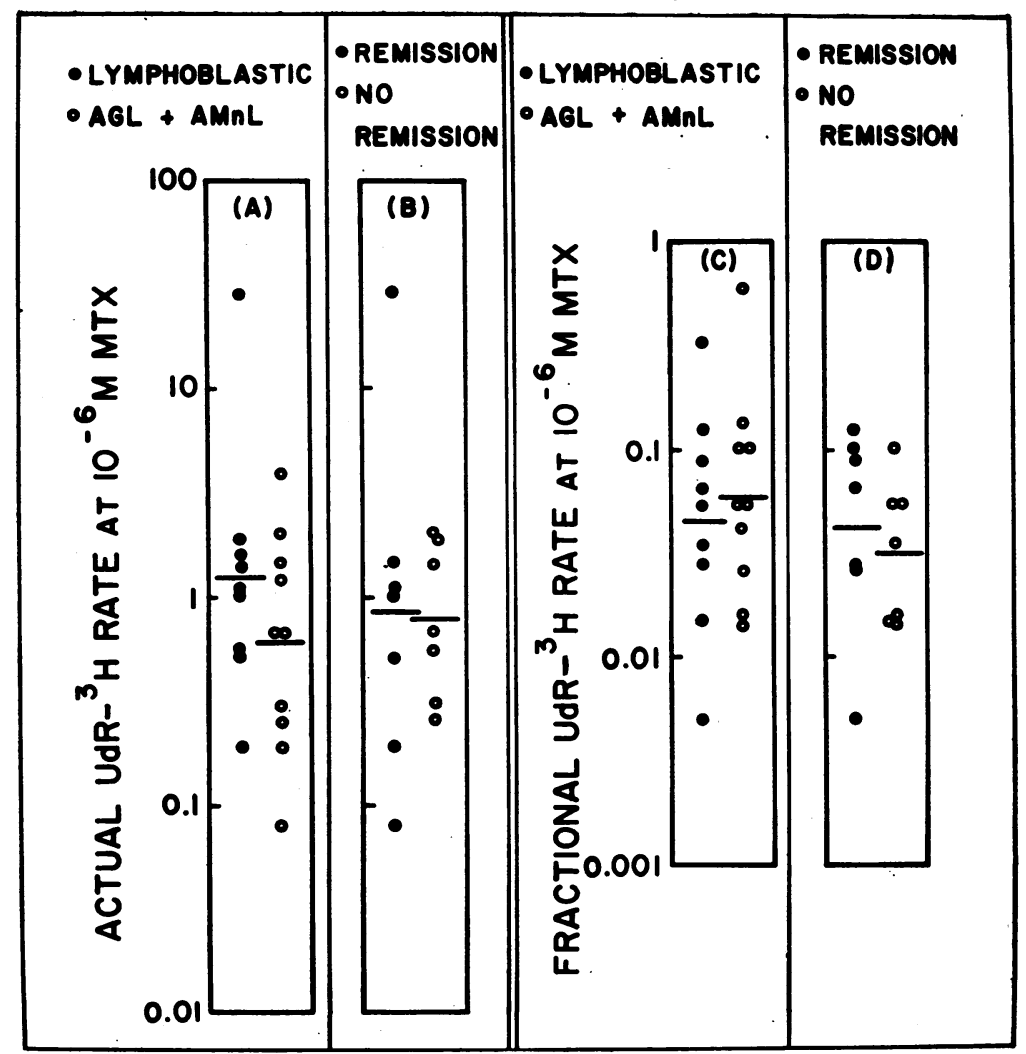

FIGURE 5 UdR- ${ }^{8} \mathrm{H}$ incorporation by blasts in the presence of MTX in vitro, comparison between cell types or response to treatment. Horizontal bars represent geometric means. Rates were measured after 30 min exposure to $10^{-6} \mathrm{M}$ MTX and expressed as the actual rates per $10^{\circ}$ blasts (A and B) or as fractions of control rates, per $10^{\circ}$ blasts ( $C$ and $\left.D\right)$. There were no significant differences between patient groups. Patients had no previous exposure to MTX-folinic therapy.

\section{Calculation of Correction Factor}

The TdR incorporation rates measured during MTX infusions frequently were much different than the pretreatment (control) $\mathrm{TdR}$ rate in each infusion studied. We reasoned that the $\mathrm{UdR}$ rate corresponding to each of these $\mathrm{TdR}$ rates would likewise have risen or fallen to an equal degree were it not for the superimposed effect of MTX blocking conversion of dUMP to dTMP. Therefore, for each $\mathrm{TdR}$ rate during therapy, we calculated a corresponding $\mathrm{UdR}$ rate by increasing or decreasing the pretreatment control UdR rate to the same extent as each $\mathrm{TdR}$ rate was altered. This calculated UdR rate we took as the "control" suitable for each observed UdR rate. Then each observed UdR rate was divided by its corresponding calculated "control" and the resulting quotient, expressed as a decimal fraction, was the corrected fractional UdR rate observed during therapy.

\footnotetext{
'Example: If the pretreatment $\mathrm{TdR}$ and $\mathrm{UdR}$ rates were 250 and 100 respectively but at the end of the MTX infusion were found to be 1000 and 2 , then the $T d R$ rate was $(1000) /(250)$ or four times its control rate and the control UdR rate at this time would not have been 100 , but would have been closer to $(1000) /(250) \times 100$ or 400 . Thus, a UdR
}

\section{RESULTS}

\section{Clinical results}

Remission rate. Five complete and seven partial remissions followed 25 courses of treatment in 21 patients (Table I). The complete remissions lasted an average of $23 \mathrm{wk}$, the partial remissions $6 \mathrm{wk}$. The remission rate in lymphoblastic disease was $60 \%$, in AGL and AMnL, $30 \%$.

rate of 2 would not be (2)/(100) of control but (2)/(400) or a fractional rate of 0.005 . If then $24 \mathrm{hr}$ after the MTX infusion ended, the TdR and UdR rates had changed to 25 and 10 respectively, the $\mathrm{TdR}$ rate would have been $(25) /(250)$ of control and the new calculated control UdR rate, $(25) /(250) \times 100$ or 10 . At this time, an observed UdR rate of 10 would be $(10) /(10)$ of its control or a fractional rate of 1 . This could indicate blockade of dUMP conversion had been abolished because even though the actual values of both rates had changed relative to pretreatment values, the pretreatment ratio of $T d R$ and UdR rate was restored. 


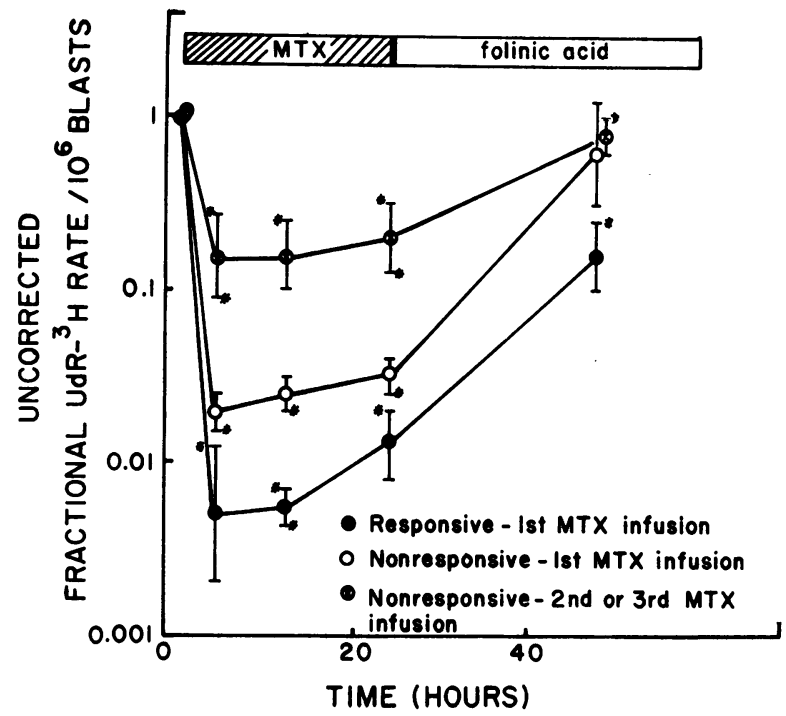

FIgURE 6 UdR- ${ }^{3} \mathrm{H}$ incorporation by blasts exposed to MTX in vivo-comparison between responsive and nonresponsive patients. Circles are geometric means $\pm 1 \mathrm{SE} ; *=$ significant difference $(P<0.05)$ between means at that time point. Compare means with asterisks at corresponding positions on the horizontal bars. Rates were calculated per $10^{\circ}$ blasts and expressed as fractions of the pretreatment rate. No corrections were applied.

Rapid and profound changes occurred in peripheral blast counts during treatment. Fig. 3 compares the responses of lymphoblastic and AGL and AML cells during the first cycle of therapy. In lymphoblastic disease, the maximum rate of peripheral blast count decline was initiated early, averaged ${ }^{8} 0.76 \mathrm{logs} / 24 \mathrm{hr}$ and usually continued over the cycle period of 4 days. An average decrease in blast count of 1.64 logs occurred with the first cycle. In AGL and AMnL, the maximal rate of disappearance of blasts from the peripheral blood was delayed for up to $24 \mathrm{hr}$ after the start of therapy, was $0.43 \mathrm{logs} / 24 \mathrm{hr}$, and was not sustained. The average decrease in count of $0.77 \operatorname{logs}$ was less than that seen in patients with lymphoblastic disease $(P<0.05)$. With continued therapy, the patients going into remission showed greater decreases in blast counts than those in whom no remission occurred.

In some cases, the decrease in blasts was obtained at the cost of profound decreases in platelets and neutrophils. This usually precluded remission since treatment had to be stopped, and blast regrowth outstripped the reappearance of normal elements.

In other cases, therapy failed to produce a remission because the decrease in the blast count became pro-

${ }^{8}$ Averaging logarithms of numbers yields their geometric, not arithmetic mean. Where responses are lognormally distributed, the geometric mean is a better measure of central tendency than is the arithmetic mean.

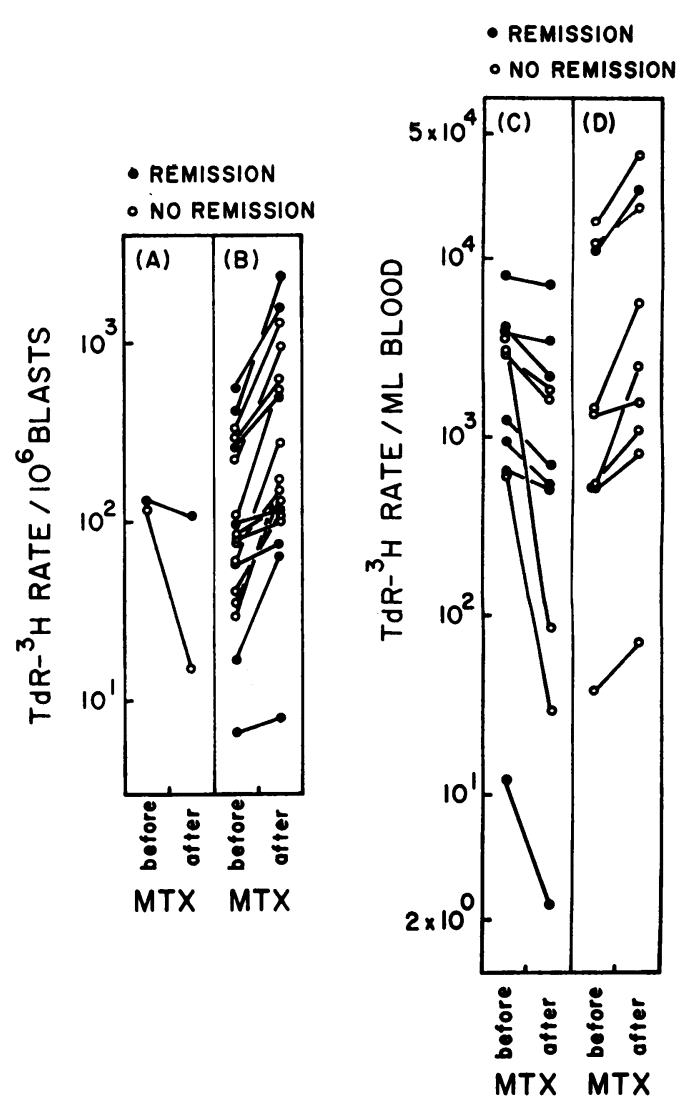

FIGURE 7 TdR- ${ }^{8} \mathrm{H}$ incorporation by blasts before and after MTX exposure in vivo. Rates were measured just after the 24th hr of MTX infusion and calculated per $10^{8}$ blasts (A and $B$ ) or per blasts in $1 \mathrm{ml}$ of blood (C and D). They were classified according to whether they were lower ( $A$ and C) or higher ( $B$ and $D$ ) than pretreatment values, and subclassified according to whether the patients did ( $\bullet$ ) or did not (O) go into remission with continued MTX-folinic therapy.

gressively less marked with each cycle. For example, the blast count decreases after three successive infusions of MTX and folinic acid in patient A. B. with AGL were 1.1 logs, 0.3 logs, and 0.1 logs. MTX therapy had to be abandoned, even though no toxicity was encountered, because it failed to produce a change in the size of the leukemic cell population.

Toxicity. Neutropenia and thrombocytopenia were the most frequent and important toxic effects (Table III). Of the two, the neutropenia was relatively more severe, occurred earlier, and was associated with serious infection in five cases, one of which ended fatally. The decline in the neutrophil count during a course of therapy averaged $1 \mathrm{log}$ for the group. No visceral hemorrhages followed drug-induced thrombocytopenia, and the decline in the platelet count during a course of therapy averaged 0.5 logs for the group. Mucositis consisted of erythema 
or nonconfluent punctate denuded areas (mild) or confluent denuded areas of mucosa (moderate) and was much less significant than the hematological toxicity. Recurrent pain associated with an audible friction rub in the left upper quadrant was observed in five instances. A maculopapular skin rash due to biopsy-proven capillaritis occurred in two patients, but there was no microhematuria or azotemia. Derangements of liver function were not detected.

\section{Biochemical results}

Pretreatment deoxynucleoside incorporation rates. Blast counts and deoxynucleoside incorporation rates/ million blasts were usually stable in the days before therapy. In some cases, however, they were changing, and therefore the control rates used were those determined just before each therapy cycle.

Fig. 4 shows the pretreatment UdR incorporation rate; there was no difference between responsive and nonresponsive patients or between different types of leukemia, regardless of how the rate of incorporation was expressed. Similarly, no differences could be detected between the $\mathrm{TdR}$ rates of these patient categories (not shown).

Effect of $M T X$ in vitro on $U d R$ incorporation. The in vitro effect of MTX $\left(10^{-6}\right.$ moles/liter $)$ on the rate of $\mathrm{UdR}$ incorporation by blasts studied before therapy is shown in Fig. 5. The results are classified according to disease type or subsequent clinical response to MTX therapy. Within each group, the rates are expressed in two ways: the actual $\mathrm{UdR}$ rates at $10^{-6}$ moles/liter are shown in Fig. $5 \mathrm{~A}$ and $5 \mathrm{~B}$, and the UdR rates expressed as fractions of their respective controls; these

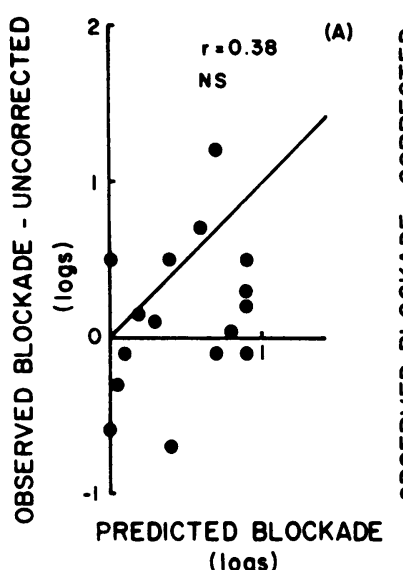

(logs)

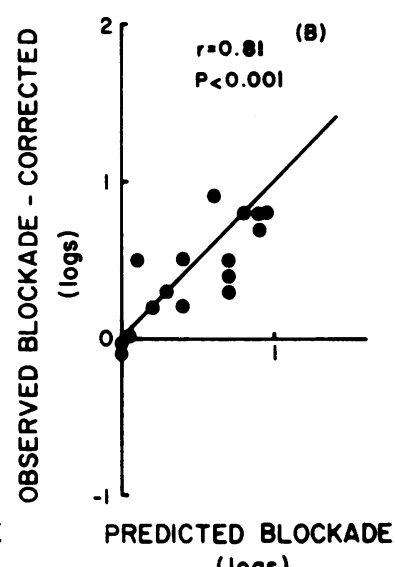

(logs)
Figure 8 Correlation between observed and predicted blockade of UdR- ${ }^{8} \mathrm{H}$ incorporation during therapy. Data are for only the 1st log of blockade. (A) Observed blockade calculated without correction for changes in $\mathrm{TdR}-{ }^{8} \mathrm{H}$ rate. Negative values for blockade represent increases in UdR- ${ }^{8} \mathrm{H}$ rate above pretreatment values. (B) Same data corrected for changes in $\mathrm{TdR}-{ }^{8} \mathrm{H}$ rate.
TABLE III

Toxicity of High Dose Methotrexate-Folinic Acid Therapy in Patients with Acute Leukemia in Relapse

\begin{tabular}{lc}
\hline \multicolumn{1}{c}{ Toxicity } & $\begin{array}{c}\text { Number of courses/ } \\
\text { Total number }\end{array}$ \\
\hline Marrow & $17 / 25$ \\
Neutropenia* & $14 / 25$ \\
Thrombocytopenia* & \\
Gastrointestinal & $9 / 25$ \\
Anorexia or vomiting & $6 / 25$ \\
Mild mucositis $\ddagger$ & $2 / 25$ \\
Moderate mucositis & \\
Other & $2 / 25$ \\
Skin rash & $5 / 25$ \\
LUQ pain & $3 / 25$ \\
Alopecia & $1 / 25$ \\
Deaths &
\end{tabular}

\section{* Defined in Methods.}

$\ddagger$ Defined in "Results-Toxicity."

fractional UdR rates are shown in Fig. $5 \mathrm{C}$ and $5 \mathrm{D}$. No differences were detected between any groups regardless of how results were expressed. None of these patients had received high-dose MTX therapy before.

Effect of infusions of MTX on UdR incorporation. The effect of MTX infusions on the rate of UdR incorporation by blasts is shown in Fig. 6. Note that patients are subdivided according to which cycle of therapy was being studied. Overall, blast cells from responsive patients showed the greatest decreases of UdR incorporation. Those of nonresponsive patients studied during the 1 st infusion showed less inhibition, and the inhibition was least in the blasts of nonresponsive patients studied during the 2 nd and 3 rd treatment cycles. The responses of each group are significantly different $(P<0.05)$ from each other at the 12th hr of the MTX infusion. At all time points, the inhibition produced in cells of responsive patients was significantly greater than that in nonresponsive patients studied during the 2 nd or 3 rd infusions. In responsive patients, blasts disappeared so quickly after the 1st MTX infusion that they could not be studied thereafter.

Effect of infusions of MTX on TdR incorporation. The rate of incorporation of $\mathrm{TdR}$ into DNA of leukemic cells changed markedly during MTX infusions. The rate $/ 10^{8}$ blasts was usually increased above pretreatment values throughout MTX and folinic infusions regardless of clinical outcome of therapy. For example, when rates before treatment were compared with those at the 24th $\mathrm{hr}$ of MTX infusion, there was no difference between responsive and nonresponsive patients (Fig. $7 \mathrm{~A}$ and $7 \mathrm{~B})$, although perhaps the increase was less marked in 
responsive patients. However, if account was taken of changes in both peripheral blast count and the TdR rate $/ 10^{\circ}$ blasts by expressing results in terms of $\mathrm{TdR}$ rate/milliliter blood, most responsive cases could be separated from most nonresponsive cases. In 11 cases, the TdR rate/milliliter had fallen by the 24th $\mathrm{hr}$ of MTX infusions (Fig. $7 \mathrm{C}$ ), and seven of these went on to remission. On the other hand, of the nine cases in which the TdR rate/milliliter blood had not decreased below pretreatment values by the 24th $\mathrm{hr}$ of MTX infusion, only one went on to remission (Fig. 7 D). All the data shown in Fig. 7 pertain to studies of the 1st infusion of MTX in each patient.

Correlation between in vitro and in vivo effects of $M T X$ on UdR incorporation. As explained in the Methods section, fractional UdR rates were predicted for each MTX concentration measured during the infusions, and the fractional UdR rates actually observed were compared with this value. In both, the changes in the UdR rates were expressed as logs of decrease from pretreatment values. Fig. $8 \mathrm{~A}$ shows that there was a poor correlation between predicted and observed rates for the 1 st $\log$ of blockade, i.e., for fractional rates from 1 to 0.1 . This discrepancy can be best appreciated by noting that some UdR rates were observed to be even greater than the preinfusion rate despite the presence of MTX, giving rise to fractional rates greater than 1 . In Fig. $8 \mathrm{~A}$ these are expressed as negative values on the ordinate.

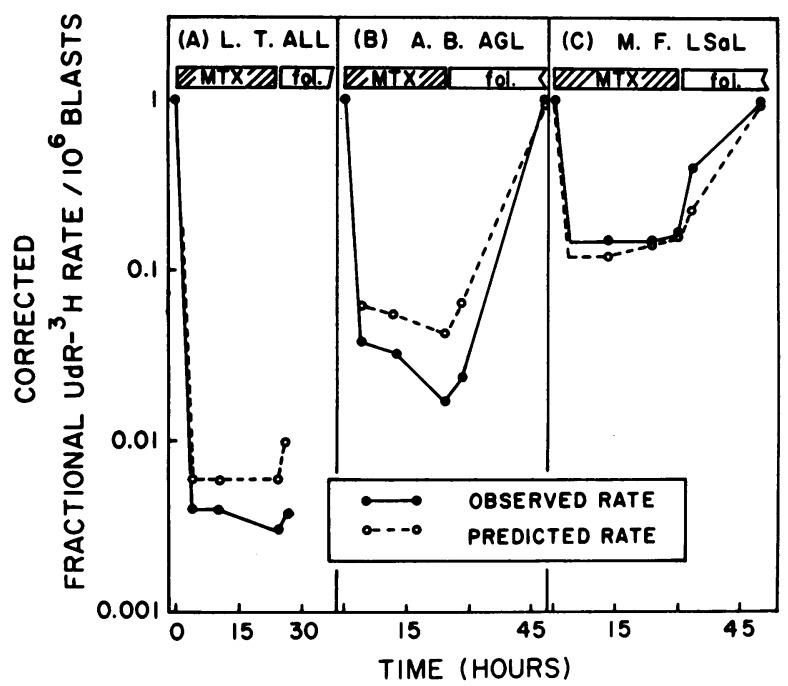

FIGURE 9 Correlation between observed and predicted UdR- ${ }^{8} \mathrm{H}$ incorporation rates during therapy. Rates were calculated per $10^{6}$ blasts. Observed $U d R^{-}{ }^{8} \mathrm{H}$ rates are fractions of pretreatment rate corrected for changes in $\mathrm{TdR}-{ }^{3} \mathrm{H}$ rates. L. T. had a complete remission, A. B. and M. F. were treatment failures. Patients' pretreatment rates were respectively $164,9.6$, and $29 \mathrm{cpm} / \mathrm{min}$ per $10^{8}$ blasts.

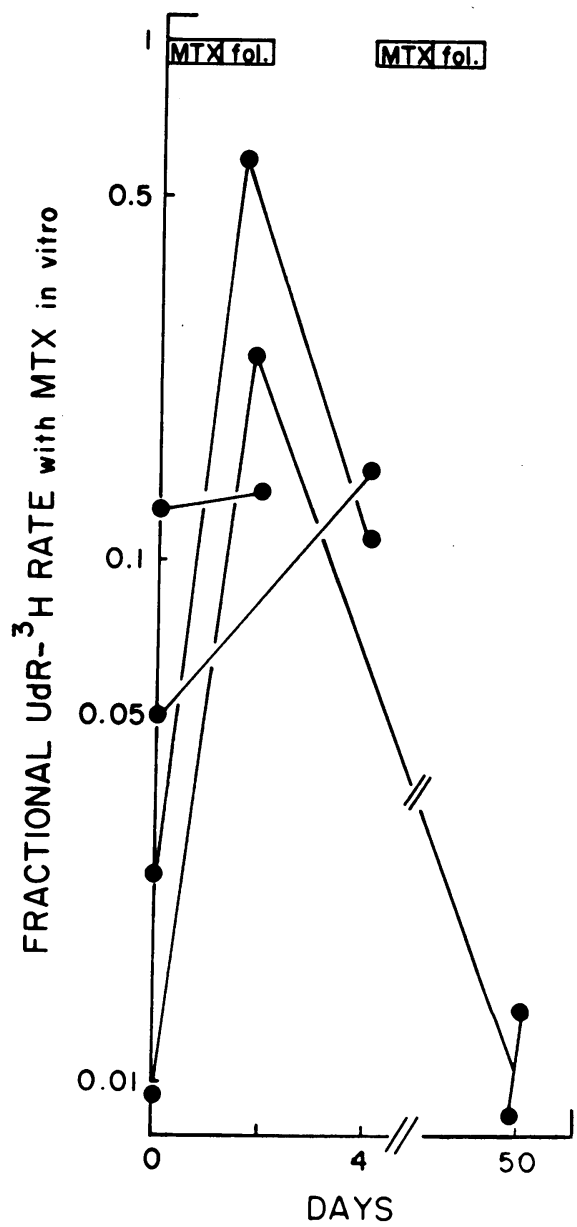

FIgURE 10 UdR- ${ }^{8} \mathrm{H}$ incorporation by blasts in the presence of MTX in vitro-changes occurring after MTX therapyresponsive patients. Rates were measured after $30 \mathrm{~min}$ exposure to $10^{-6} \mathrm{M}$ MTX in vitro, calculated per $10^{8}$ blasts, and expressed as a fraction of the control rate. These patients all went into remission.

If the UdR rates observed during infusions were expressed as fractions of a corrected pretreatment UdR rate (see Methods, "calculation of correction factor"), then there was a good correlation between predicted and observed fractional UdR rates for the 1 st log of blockade (Fig. $8 \mathrm{~B}$ ). However, the correlation between predicted and observed blockade at the 2nd and 3rd logs of blockade (fractional rates of $0.1-0.001$ ) was the same $(r=$ $0.65)$ regardless of whether or not the correction factor was applied and was significant $(P<0.05)$. The regression line relating the predicted with the corrected observed blockade had a slope of $1.10 \pm 0.07\left(b \pm S_{b}\right)$, indicating there was no systematic error in predicting blockade (slope not significantly different from 1).

Fig. 9 shows three examples of studies correlating observed with predicted UdR rates during drug infu- 
sions, using appropriate correction factors derived from the concomitantly measured $\mathrm{TdR}$ rates (not shown).

When this correction was applied to the fractional UdR rates shown in Fig. 6, the differences between the rates of the patient groups narrowed, but patients studied during their 1st MTX infusion still showed significant differences from nonresponsive patients studied during their 2nd or 3rd MTX infusion.

When the corrections were applied to the pretreatment UdR rates to generate new "control" UdR rates, it was assumed that the pretreatment ratio of $\mathrm{TdR}$ to UdR incorporation rates would remain constant were it not for the presence of MTX. It would be therefore important to show that the ratio of TdR to UdR incorporation actually did remain stable if unperturbed by therapy. The ratio of $T d R$ to $U d R$ rate was $3.2 \pm 0.2$ (SE) for both lymphoblastic and AGL and AMnL cells and was constant for a given patient despite changes in the dayto-day values of both rates. The correlation coefficient between the two rates was 0.99 for lymphoblastic cells and 0.98 for AGL and AMnL cells.
Changes in resistance of cells to MTX in vitro. When cells were tested for sensitivity to MTX in vitro during therapy, changes occurred. In the patients whose disease subsequently remitted (Fig. 10), the fractional UdR incorporation rate at $10^{-6} \mathrm{M} \mathrm{MTX}$ in vitro measured in cells harvested during the folinic acid infusions was increased above the pretreatment value but appeared to be returning toward base line levels thereafter. Blast counts declined so rapidly after the first cycle of therapy in this group that it was impossible to perform serial studies in all patients. In one case, complete remission occurred with only one infusion of MTX and folinic acid, even though the cells tested during the folinic infusion showed a fractional UdR rate 25 -fold higher than the pretreatment cells. When the patient relapsed 50 days later, the cells had regained the original pretreatment fractional UdR rate and again the patient remitted on MTX-folinic therapy.

In patients in whom no remission occurred (Fig. 11), the in vitro responses to MTX of leukemic cells surviving treatment appeared different. Blasts surviving

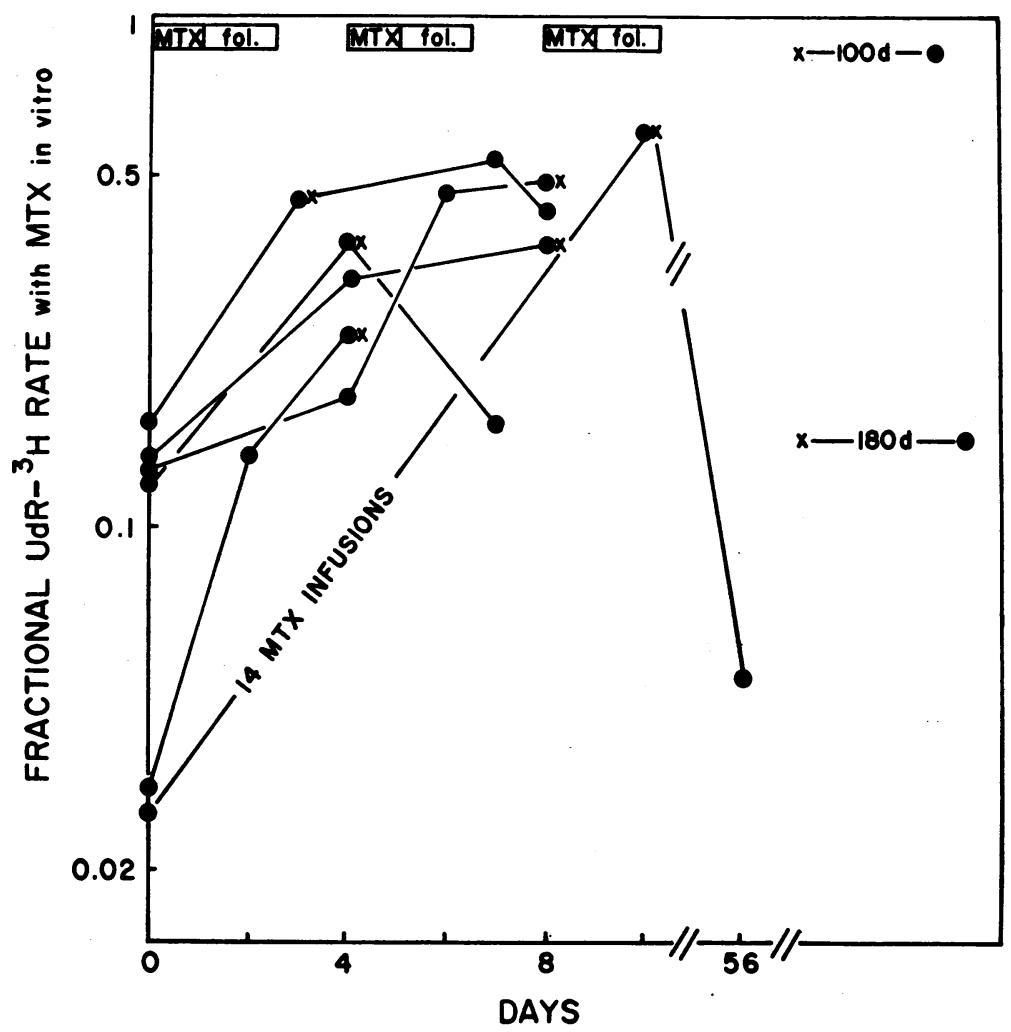

FIGURE 11 UdR- ${ }^{3} \mathrm{H}$ incorporation by blasts in the presence of MTX in vitro-changes occurring after MTX therapy-nonresponsive patients. Rates were measured after $30 \mathrm{~min}$ exposure to $10^{-6} \mathrm{M}$ MTX, calculated per $10^{\circ}$ blasts, and expressed as a fraction of the control rate. One patient, D. D. (ALL), remitted but relapsed after 14 MTX infusions, when his cells became resistant to MTX in vitro. Remission could not be induced in the others. $X=$ termination of MTX-folinic therapy; $d=$ days. 
TABLE IV

Leukemic Cell Dihydrofolate Reductase Activity During Methotrexate-Folinic Acid Therapy

\begin{tabular}{|c|c|c|c|c|c|c|}
\hline \multirow[b]{2}{*}{ Name } & \multirow[b]{2}{*}{ Disease } & \multicolumn{2}{|c|}{ DHFR* activity at $\mathrm{pH} 7.0$} & \multicolumn{2}{|c|}{ DHFR activity at $\mathrm{pH} 8.5$} & \multirow[b]{2}{*}{ Response } \\
\hline & & $\begin{array}{c}\text { Before MTX } \\
\text { infusion }\end{array}$ & $\begin{array}{l}\text { At end of } \\
\text { MTX infusion }\end{array}$ & $\begin{array}{l}\text { Before MTX } \\
\text { infusion }\end{array}$ & $\begin{array}{c}\text { At end of } \\
\text { MTX infusion }\end{array}$ & \\
\hline A. & & \multicolumn{2}{|c|}{ $\mu$ moles $/ \mathrm{hr}$ per $\mathrm{mg}$} & \multicolumn{2}{|c|}{ umoles $/ \mathrm{hr}$ per $\mathrm{mg}$} & \\
\hline \multirow[t]{3}{*}{ L. T. } & ALL & & & & & \\
\hline & $4-22-67$ & $<0.005$ & $<0.005$ & $<0.005$ & $<0.005$ & Complete remission \\
\hline & 6-14-67 & $<0.005$ & $<0.005$ & 0.056 & 0.034 & Complete remission \\
\hline A. P. & RSaL & 0.030 & $<0.005$ & 0.020 & 0.005 & Complete remission \\
\hline D. D. & ALL & 0.026 & $<0.005$ & 0.005 & 0.005 & Partial remission \\
\hline \multicolumn{7}{|l|}{ B. } \\
\hline L. F. & $\mathrm{AMnL}$ & 0.015 & $<0.005$ & 0.017 & 0.025 & Partial remission \\
\hline M. E. & $\mathrm{AMnL}$ & 0.039 & $<0.005$ & 0.036 & 0.070 & Partial remission \\
\hline M. P. & $\mathrm{LSaL}$ & 0.100 & $<0.005$ & 0.100 & 0.240 & Partial remission \\
\hline \multicolumn{7}{|l|}{ C. } \\
\hline A. $S$. & AGL & $<0.005$ & $<0.005$ & $<0.005$ & $<0.005$ & $\begin{array}{l}\text { Indeterminate, probable } \\
\text { remission }\end{array}$ \\
\hline J. V. & LSaL & $<0.005$ & $<0.005$ & $<0.005$ & 0.015 & $\begin{array}{l}\text { Indeterminate, probably } \\
\text { no remission }\end{array}$ \\
\hline \multirow[t]{3}{*}{ A. B. $\ddagger$} & $\begin{array}{l}\text { LSaL } \\
\text { AGL }\end{array}$ & $<0.005$ & $<0.005$ & $<0.005$ & $<0.005$ & No remission \\
\hline & $4-19-67$ & 0.023 & 0.009 & 0.073 & 0.163 & No remission \\
\hline & $11-29-67$ & 0.030 & 0.010 & 0.005 & 0.034 & No remission \\
\hline W. B. & AGL & 0.082 & 0.095 & 0.180 & 0.340 & No remission \\
\hline D. D. & ALL & 0.033 & 0.033 & 0.220 & 0.250 & No remission \\
\hline M. F. $\ddagger$ & LSaL & - & 0.120 & - & 0.790 & No remission \\
\hline
\end{tabular}

* DHFR, dihydrofolate reductase enzyme.

$\ddagger$ Patients received MTX within the week before present study.

successive infusions of MTX and folinic acid showed a progressive rise in the fractional UdR rate at $10^{-8} \mathrm{M}$ MTX in vitro, and these high fractional UdR rates were slow to return to pretreatment levels compared with the responsive cases. Thus, when therapy finally had to be abandoned in the nonresponsive group (indicated in Fig. 11 by the $\mathrm{X}$ 's), the fractional UdR rates were uniformly higher $(0.26-0.5)$ than the last tests available in the responsive group $(0.1-0.15)$. Two patients had been treated 100 and 180 days before these biochemical studies were being done, and both had failed to respond. When tested for the first time, their blasts still showed fractional UdR rates of $10^{-6} \mathrm{M}$ MTX which were higher than the patients tested before any treatment was given (compare with Fig. 5).

(g) Changes in DHFR enzyme activity. The changes in DHFR enzyme activity measured in relation to therapy are summarized in Table IV. Enzyme activity may be measured by performing the assay at $\mathrm{pH} 8.5$ because the MTX-enzyme complex dissociates, but the value thus obtained probably does not represent the level of free intracellular enzyme. Rather, enzyme activity measured at the lower $\mathrm{pH}$ of 7.0 probably more closely approximates the level of free enzyme activity present in the intact cell (35).

In patients with the most favorable responses, enzyme activity measured at $\mathrm{pH} 7.0$ could not be detected during MTX infusions while that at $\mathrm{pH} 8.5$ was reduced or unchanged (Table IV A). In patients with partial remissions, activity at $\mathrm{pH} 7.0$ was also undetectable but activity at $\mathrm{pH} 8.5$ rose slightly near the end of the infusion. (Table IV B). When the enzyme levels could be detected in the cells of patients who did not obtain a remission, the activity at $\mathrm{pH} 7.0$ was not completely inhibited and even rose in some patients; enzyme activity at $\mathrm{pH} 8.5$ was regularly increased by the end of the infusion (Table IV C).

\section{DISCUSSION}

\section{Clinical results}

Patients who had lymphoblastic leukemia and who had not previously been treated with MTX obtained the best clinical responses, and the results compared favorably with other modes of therapy of leukemia relapsing after initial remission $(36,37)$. 
Gastrointestinal toxicity was not a major problem, but myelosuppression was more severe than was anticipated from a similar schedule in nonleukemic individuals (7). This may have been due to a reduced granulocyte reserve pool and an increased MTX sensitivity of the normal elements in the leukemic marrow compared with the normal elements in the marrows of patients with carcinoma (38). In addition, after patients with leukemia went into remission they experienced less myelotoxicity on the same high dose MTX schedule.

One of the most striking results of therapy was the rapid fall of the peripheral blast count. (Fig. 3). The logarithm of the count frequently decreased linearly with time, implying exponential or random disappearance of cells. This rapid decline is difficult to explain if it is assumed that MTX affects only the proliferating fraction of the circulating blasts. This is because most circulating blasts are in a nonproliferative $G_{1}$ or $G_{n}$ phase $^{\circ}(39,40)$ and therefore should not be susceptible to the effects of MTX (17). Therapy may have inhibited DNA synthesis in anatomical sites which had more proliferative potential than the blood, e.g. marrow and which maintained the input of blasts to the vascular compartment. Hence, the rapid fall of circulating blasts could be explained by inhibition of entry of blasts into the circulation from these sites rather than direct "kill" of circulating blasts. If so, then in the untreated patient there would be a significant "death rate" and rapid turnover of peripheral blasts, and the synthesis of new cells required to maintain the steady-state peripheral blast count could approximate $35 \times 10^{n}$ cells $/ 24 \mathrm{hr}$ (20 kg child with 10,000 blasts/ $\mathrm{mm}^{3}$ blood). Another explanation for the marked changes in the blast count in the peripheral blood might be that MTX produces a direct lethal effect on blasts regardless of their place in the mitotic cycle. Some evidence exists that this may occur with high doses of MTX in experimental systems (41).

\section{Biochemical results}

The test system. Attempts at predicting chemotherapeutic results based on drug effects on cells in vitro have been numerous (42-52) but none have achieved practical application. Several prerequisites for success of such attempts may be suggested. The mode of drug action must be known so that the in vitro test can monitor biochemical disturbances closely related to the drugs' cytostatic and cytocidal effects. In the present study, we chose to monitor the effects of MTX on DNA synthesis at the step of dUMP conversion to dTMP (Fig. 1) because the evidence from viral, bacterial, and animal systems suggested that MTX produces cytostatic and

\footnotetext{
${ }^{9} \mathrm{G}_{1}$ period of cell cycle between mitosis (M) and $S$. If cells do not resume DNA synthesis $G_{1}=G_{0}$. $S=$ period of DNA synthesis.
}

cytocidal effects primarily by blocking this step $(17,19)$. In addition, in any test system, results must be replicable, quantifiable over a-wide range of drug concentrations, and rapidly obtainable. Furthermore, clinical-biochemical correlates must be made on a quantitative basis and must cover a wide range of responses to be clinically useful. In this study, the rate of incorporation of deoxynucleosides into DNA was measured instead of the total amount incorporated after a fixed incubation period to ensure greater accuracy. Thus, if incorporation was not linear with time in control incubations, it was presumed DNA synthesis had ceased due to unfavorable in vitro culture conditions and results were not used. This method of measurement ensured reproducibility and allowed conversion of data to the logarithmic form (53). Thus, the effect of drug on the UdR incorporation rate could be accurately quantitated over several logs of dose and response.

Potential sources of error in the test system considered were: varying rates of phosphorylation of deoxynucleosides, cleavage of deoxyribose from the pyrimidine bases, and exchange of ribose for deoxyribose (54). Error from these was judged minimal because incorporation was linear, rate determinations were replicable, and the ratio of $\mathrm{TdR}$ to $\mathrm{UdR}$ incorporation rate remained constant (Table II).

The sensitivity of blast cells to MTX in vitro before institution of treatment appeared stable as judged by the reproducibility of the fractional UdR rates. Serial pretreatment studies were not performed in patients whose blast counts were rapidly changing without therapy. Perhaps in such cases, the sensitivity of the blasts to MTX in vitro might not be as constant as those reported here. Also, comparisons of sensitivity of blasts in blood and marrow were not made and hence the relationship between the responses of peripheral and marrow blasts was not established. However, the system of study described here is easily adaptable to the blasts of the marrow, and investigations are currently underway to determine the effects of therapy on this potentially more important compartment of the leukemic cell population.

\section{Clinical-biochemical Correlates}

Pretreatment deoxynucleoside incorporation rates. It is believed that the larger the growth fraction of a population, the faster is the growth rate of that population, and the more susceptible is it to the lethal effects of antimetabolites (55). One would expect that the deoxynucleoside incorporation rates $/ 10^{\circ}$ blasts would be some measure of the relative sizes of the growth fractions of different leukemic cell populations. Thus, the higher the deoxynucleoside incorporation rates might occur in populations most susceptible to MTX. However, we saw no relationship between the deoxynucleoside in- 
corporation rate of peripheral leukemic blasts and the clinical outcome of therapy (Fig. 4).

Effect of $M T X$ in vitro on UdR incorporation. Necheles, Maniatis, and Allen (56) studied the in vitro effects of MTX on UdR incorporation by leukemic marrow cells. They reported that $2.2 \times 10^{-8} \mathrm{M}$ MTX produced $65 \%$ or more inhibition in cells of responsive cases and $45 \%$ or less in cells of clinically resistant cases. In our study this drug concentration produced 98\% inhibition of UdR incorporation in cells of previously untreated patients (range $93-99.5 \%$ ) but did not produce a greater inhibition in cells of patients who responded well to therapy either at $2.2 \times 10^{-6} \mathrm{M} \mathrm{MTX}$ or at $10^{-6} \mathrm{M}$ MTX (Fig. $5 \mathrm{D}$ ). However, comparison of our data with that of Necheles et al. may not be valid due to differences in tissues sampled, duration of incubation of cells with drug, methods of measuring drug effects, and differences in therapy protocols. Thus, in those patients who had not previously received MTX in high dosage, we could not predict the results of MTXfolinic therapy solely on the basis of the in vitro effect of MTX on UdR incorporation by blasts. Additional factors that were not taken into account by this in vitro test must therefore have contributed to the outcome. A major drawback to the studies of drug effects on cells has been the failure to measure the adaptive resistance of the cells to a particular antimetabolite, i.e., resistance developing rapidly during the first exposure to the drug. Thus, leukemic cells initially sensitive in vitro to azauridine (57), and marrow cells to asparaginase (58), may become resistant to the drug relatively quickly upon being exposed to these agents in vivo. In fact, failure of the cells to rapidly become resistant upon drug exposure may be a definition of sensitivity which is most relevant to prediction of clinical responsiveness to antimetabolite therapy. Other approaches have been taken in attempts to predict the outcome of MTX therapy based on in vitro testing of target cells. Kessel, Hall, Roberts, and Wodinsky (59) reported a close correlation between in vitro uptake of MTX by murine leukemia cells and in vivo effects of MTX therapy as judged by prolongation of life of leukemic mice. Several authors, including Fischer (60), have shown defective transport of MTX to be a mechanism of resistance of animal tumor cells to the antifolate. While there is a correlation between antileukemic effects of MTX therapy and in vitro MTX up`ake by leukemic cells of humans (43), overlap in the in vitro responses of the cells may limit the usefulness of this method of predicting the outcome of therapy in individual cases.

Effects of infusions of MTX on UdR incorporation. The relationship between the in vivo effects of MTX on UdR incorporation and the therapeutic outcome was examined. As can be seen from Fig. 6, the patients who went into remission on therapy had the greatest degree of reduction in UdR incorporation. During the MTX infusion, the cells of responsive patients showed UdR incorporation rates which were $0.005-0.013$ of the pretreatment rate. In the resistant patients studied during the 2nd and 3rd MTX infusions, the UdR incorporation rates were $0.15-0.2$ of the pretreatment rates, significantly greater than the responsive group. Thus, the measurements of the uncorrected fractional $U d R$ incorporation rates during MTX infusions did bear some relationship to the clinical outcome of therapy, but there was considerable overlap in results of the first infusion between responsive and nonresponsive patients.

Correlation between in vitro and in vivo effects of $M T X$ on UdR incorporation. There was little correlation between the fractional UdR incorporation in the presence of MTX in vitro and that seen with in vivo drug exposure for the 1 st $\log$ of blockade. However, when the effects of the changing $\operatorname{Tr} R$ incorporation rate were compensated for as described in the Methods section, there was excellent agreement between predicted and observed fractional UdR rates. It thus appears possible to predict how much blockade of dUMP conversion to dTMP can be produced in a given population of cells by a given treatment with MTX, but not what the actual UdR rate will be because of the unpredictability of the effect on the TdR rate. That is, it may be possible to control the degree of the "thymine-less" state to which the cells are subjected. However, there was little difference between responsive and nonresponsive patients in respect of the degree and duration of blockade of dUMP conversion to dTMP, at least during the 1st MTX infusion. It may be that a critical difference between the blasts of the two patient groups was that the leukemic cells of nonresponsive patients were able to tolerate the thymine-less state for a longer period of time without suffering irreversible damage. This in fact may be the reason why infrequent large doses of MTX are more effective than small frequent doses. Some proliferating cells, e.g. susceptible tumor cells, may be unable even for a brief period to tolerate a thymine-less state while others, e.g. normal marrow cells or "resistant" tumor cells, may be tolerant of such a state being only arrested but not killed by drug exposure. We could predict how much blockade could be produced but not how long a given degree of blockade of UdR incorporation had to be maintained to produce maximum kill of leukemic cells. To predict how much kill would be produced for each hour of a given degree of blockade, one would need an in vitro cloning system or its equivalent and none such is available for human leukemic blasts directly sampled from the patient.

It is noteworthy that less blockade of UdR incorporation was seen in blasts of nonresponsive patients stud- 
ied during the 2 nd and 3 rd infusions, and in vitro their blasts were resistant to MTX as judged by the higher fractional $U d R$ rates seen after half-hour exposure to MTX at $10^{-6}$ moles/liter. This biochemical resistance probably resulted from blasts surviving an MTX infusion, acquiring detectable resistance to MTX during the folinic "rescue" procedure, and then losing this "resistance" less rapidly than the blasts of responsive patients.

Effects of MTX infusions on TdR incorporation. The $\mathrm{TdR}$ incorporation rate during the MTX infusion did not seem related to the therapeutic outcome, if one compares the rates $/ 10^{\circ}$ blasts. Regardless of how the patients fared, in most cases the $\mathrm{TdR}$ incorporation rate at the end of the MTX infusion was elevated above pretreatment values, although the rise perhaps was less marked in the cells of responsive patients (Fig. $7 \mathrm{~B}$ ). These changes in $T d R$ rates were unpredictable and were responsible in large measure for the fact that the UdR rates did not coincide with those expected from pretreatment in vitro studies. However, when the product $\mathrm{TdR}$ rate $/ 10^{\circ}$ blasts times blast count in million $/ \mathrm{ml}$ of blood ( $\mathrm{TdR}$ rate/milliliter) was determined before therapy and compared with the postinfusion value, segregation of responsive from nonresponsive patients was partially achieved. Thus, if by the end of the 1 st infusion the $\mathrm{TdR}$ rate/milliliter remained above pretreatment values, remission was unlikely, while in the group in whom the $\mathrm{TdR}$ rate/milliliter decreased below pretreatment values, the majority went on to remission. In all patients, the blast count fell by the end of the infusion, and no difference could be seen in the degree of decline between responsive and nonresponsive patients. Roberts and Hall (61) reported that after single doses of MTX, the TdR rate decreased or did not change in the ALL cells and rose in the AGL cells. In that study, biochemical results were not correlated with the outcome of therapy in individual cases, but it is well established that ALL is much more responsive to MTX therapy than is AGL or AMnL.

Studies of cultured murine leukemia cells have shown that MTX depresses TdR incorporation into DNA by L5178Y mouse leukemia cells from a rapidly growing culture but has little effect on TdR incorporation by cells from resting cultures. Corresponding to these different effects on $\mathrm{TdR}$ incorporation are great differences in the lethal effects of the drug. For example, cells in the log cultures are killed at a 6 -fold greater rate than are cells from resting cultures. ${ }^{10}$ In cells most susceptible to the cytotoxic effects of MTX, the drug may interfere with purine biosynthesis and block DNA synthesis on this basis (hence suppress $\mathrm{TdR}$ and $\mathrm{UdR}$ incorporation) as

\footnotetext{
${ }^{10}$ Hryniuk, W., G. Fischer, and J. Bertino. Unpublished observations.
}

well as blocking UdR incorporation at the additional step of dUMP conversion to dTMP. However, after many hours, MTX might affect $\mathrm{TdR}$ incorporation in several other ways besides interfering with purine biosynthesis, e.g., by synchronizing cells, inducing TdRkinase, killing cells, and deranging movements of cells between body compartments. Thus, a depression of the $\mathrm{TdR}$ incorporation rate occurring during an MTX infusion would probably not be explicable by only one effect of the drug, but it may be an important sign that the cell population is sensitive to the cytocidal effects of MTX.

Patterns in DHFR enzyme activity. Increased levels of DHFR enzyme appeared in extracts of blasts refractory to therapy (Table IV c), but not in blasts responding to therapy (Table IV $a$ and IV b). Increased DHFR levels have been repeatedly observed in extracts of normal and malignant cells surviving MTX exposure (6266). Roberts and Hall could not detect increased DHFR after MTX therapy if folate were used as substrate (63), perhaps for technical reasons (35), since Rothenberg, Schreiber, and Clark showed increased folate-reducing activity in extracts of leukemic cells clinically resistant to MTX (67). Dihydrofolate, not folate, is the probable physiological substrate for DHFR enzyme (68), hence alterations in enzyme activity with dihydrofolate as substrate would be more relevant to MTX-resistance mechanisms.

Hillcoat, Swett, and Bertino showed DHFR enzyme activity of human cells in culture rose during logarithmic growth (66). It then declined during the stationary phase, possibly due to proteolysis, but MTX bound to DHFR prevented enzyme decay. Murine L1210 leukemia cells in culture did not show increased enzyme activity during logarithmic growth and MTX failed to produce accumulation of bound enzyme." Furthermore, the mouse cells were more sensitive to MTX than were the human cells. Therefore, an additional difference of major importance between these two cell types in culture or between AGL or AMnL and ALL leukemia in humans may be that in cells showing an enzyme rise, DHFR is turning over faster. This capacity for rapid enzyme synthesis, associated with proliferating cells of a growth fraction which is slowly turning over would be responsible for the relative lack of sensitivity of these cells to MTX therapy. In any case, of all the parameters studied, the patterns observed in the DHFR enzyme activity of blasts during chemotherapy showed the best correlation with clinical outcome. Unfortunately, it was not possible to detect DHFR activity before therapy in many cases, and, hence, the usefulness of this assay in modulating therapy might be quite limited.

${ }^{11}$ Hillcoat, B. Personal communication. 


\section{ACKNOWLEDGMENTS}

The technical assistance of Grete Myhre and Inger-Anne Skjeltorp is gratefully acknowledged. Thanks to Doctors R. Zanes, S. Finch, and D. Clement for allowing their patients to be studied; and to Doctors $R$. Capizzi and $P$. Guzman and the medical house staff of the Yale-New Haven Hospital for their cooperation. The monumental patience and diligence of Linda Grenfell who typed this manuscript is hereby recorded.

This research was supported by U. S. Public Health Service Grants CA 08010 and CA 08341.

\section{REFERENCES}

1. Goldin, A., J. M. Venditti, S. R. Humphreys, D. Dennis, and N. Mantel. 1955. Studies on the management of mouse leukemia (L1210) with antagonists of folic acid. Cancer Res. 15: 742.

2. Perrin, J. C. S., A. M. Mauer, and T. D. Sterling. 1963. Intravenous methotrexate (amethopterin) therapy in the treatment of acute leukemia. Pediatrics. 31: 833 .

3. Huguley, C. M., Jr., W. R. Volger, J. W. Lea, C. C. Corely, and M. E. Lowrey. 1965. Acute leukemia treated with divided doses of methotrexate. Arch. Intern. Med. 115: 23.

4. Acute Leukemia Group B. 1961. New treatment schedule with improved survival in childhood leukemia. Intermittent parenteral versus daily oral administration of methotrexate for maintenance of induced remission. J. Amer. Med. Ass. 194: 75.

5. Djerassi, I. 1967. Methotrexate infusions and intensive supportive care in the management of children with acute lymphocytic leukemia. Follow-up Report. Cancer Res. 27 (Pt. 1) : 2561.

6. Hertz, R., D. M. Bergenstal, M. B. Lipsett, E. B. Price, and T. F. Hilbish. 1959. Chemotherapy of choriocarcinoma and related trophoblastic tumors in women. Ann. N. Y. Acad. Sci. 80: 262.

7. Lefkowitz, E., R. J. Papac, and J. R. Bertino. 1967. Studies of head and neck cancer. III. Toxicity of 24 hour infusions of methotrexate (NSC-740) and protection by leucovorin (NSC-3590) in patients with epidermoid carcinomas. Cancer Chemother. Rep. 51: 305.

8. Condit, P. T., B. I. Shnider, and A. H. Owens, Jr. 1962. Studies on the folic acid vitamins. VII. The effects of large doses of amethopterin in patients with cancer. Cancer Res. 22: 706.

9. Ross, C. A., and O. S. Selawry. 1966. Comparison of doses of intermittent methotrexate in lung cancer. Proc. Amer. Ass. Cancer Res. 7: 60. (Abstr.)

10. Oettgen, H. F., D. Burkitt, and J. H. Burchenal. 1963. Malignant lymphoma involving the jaw in African children. Treatment with methotrexate. Cancer. 16: 616.

11. Mead, J. A. R., J. M. Venditti, A. W. Schrecker, A. Goldin, and J. C. Keresztesy. 1963. The effect of reduced derivatives of folic acid on the toxicity and antileukemic effect of methotrexate in mice. Biochem. Pharmacol. 12: 371.

12. Sullivan, R. D., E. Miller, and M. P. Sikes. 1959. Antimetabolite-metabolite combination cancer chemotherapy. Effects of intra-arterial methotrexate-intramuscular citrovorum factor therapy in human cancer. Cancer. 12: 1248.

13. Goldin, A., J. M. Venditti, I. Kline, and N. Mantel. 1966. Eradication of leukaemic cells (L1210) by methotrexate and methotrexate plus citrovorum factor. Nature (London). 212: 1548.

14. Johns, D. G., J. W. Hollingsworth, A. R. Cashmore, I. U. Plenderleith, and J. R. Bertino. 1964. Methotrexate displacement in man. J. Clin. Invest. 43: 621.

15. Bertino, J. R. 1964. II. Preparation of normal and malignant human cells for study of resistance. Methods Med. Res. 10: 263.

16. Bertino, J. R. 1963. The mechanism of action of the folate antagonists in man. Cancer. Res. 23: 1286.

17. O'Brien, J. S. 1962. The role of the folate coenzymes in cellular division, a review. Canccr Res. 22: 267.

18. Osborn, M. J., M. Freeman, and F. M. Huennekens. 1958. Inhibition of dihydrofolic reductase by aminopterin. Proc. Soc. Exp. Biol. Med. 97: 429.

19. Rueckert, R. R., and G. C. Mueller. 1960. Studies on unbalanced growth in tissue culture. I. Induction and consequences of thymidine defisien y. Cancer. Res. 20: 1584 .

20. Lochaya-Vimokesant, S., H. S. Winchell, M. B. Fish, and M. Pollycove. 1967. Decreased de novo DNA-thymine synthesis and increased thymidine $-{ }^{3} \mathrm{H}$ incorporation into DNA by human bone marrow cultured with aminopterin. Proc. Soc. Exp. Biol. Med. 126: 621.

21. Sartorelli, A. C., H. F. Upchurch, and B. Booth. 1962. Effects of folinic acid on amethopterin-induced inhibition of the Ehrlich ascites carcinoma. Cancer Res. 22: 102.

22. Bray, G. A. 1960. A simple efficient liquid scintillator for counting aqueous solutions in a liquid scintillation counter. Anal. Biochem. 1: 279.

23. Blakely, R. L. 1960 Crystalline Dihydropteroylglutamic Acid. Nature (London). 188: 231.

24. Gagon, T. E., J. W. Athens, D. R. Boggs, and G. E. Cartwright. 1966. An evaluation of the variance of the leukocyte counts as performed with the Hemocytometer, Coulter and Fisher Instruments. Amer. J. Clin. Pathol. 46: 684.

25. Perkins, J. P., B. L. Hillcoat, and J. R. Bertino. 1967. Dihydrofolate reductase from a resistant subline of the L1210 lymphoma-purification and properties. J. Biol. Chem. 242: 4771.

26. Bertino, J. R. 1964. II. Preparation of normal and malignant human cells for study of resistance. Methods Med. Res. 10: 263.

27. Osborn, M. J., and F. M. Huennekens. 1958. Enzymatic reduction of dihydrofolic acid. J. Biol. Chem. 233: 969.

28. Fleck, A., and H. N. Munro. 1962. The precision of ultraviolet absorption measurements in the SchmidtThannhauser procedure for nucleic acid estimation. Biochim. Biophys. Acta. 55: 571.

29. Burton, K. 1956. A study of the conditions and mechanism of the diphenylamine reaction for the colorimetric estimation of deoxyribonucleic acid. Biochem. J. 62: 315.

30. Schneider, W. C. 1957. Methods in Enzymology. S. P. Colowick and N. O. Kaplan, editors. Academic Press Inc., New York. 3: 680.

31. Gornall, A. G., C. J. Bardawill, and M. M. David. 1949. Determination of serum proteins by means of the biuret reaction. J. Biol. Chem. 177: 751.

32. Snedecor, G. W. 1956. Statistical Methods. Iowa State University Press, Ames. 5th edition. 141.

33. Johnson, P. O. 1949. Statistical Methods in Research. Prentice-Hall Inc., Englewood Cliffs. 62. 
34. Snedecor, G. W. 1956. Statistical Methods. Iowa State University Press, Ames. 5th edition. 320.

35. Bertino, J. R., B. A. Booth, A. L. Bieber, A. Cashmore, and A. C. Sartorelli. 1964. Studies on the inhibition of dihydrofolate reductase by the folate antagonists. J. Biol. Chem. 239: 479.

36. Acute Leukemia Group B. 1961. Studies of sequential and combination antimetabolite therapy in acute leukemia: 6-mercaptopurine and methotrexate. Blood. 18: 431.

37. Thompson, I., T. C. Hall, and W. C. Maloney. 1965. Combination therapy of adult acute myelogenous leukemia-experience with the simultaneous use of vincristine, amethopterin, 6-mercaptopurine and prednisone. N. Engl. J. Med. 273: 1302.

38. Bruce, W. R., B. E. Meeker, and F. A. Valeriote. 1966. Comparison of the sensitivity of normal hematopoietic and transplanted lymphoma colony-forming cells to chemotherapeutic agents administered in vivo. J. Nat Cancer Inst. 37: 233.

39. Mauer, A., and V. Fisher. 1962. Comparison of the proliferative capacity of acute leukemia cells in bone marrow and blood. Nature (London). 193: 1085.

40. Killmann, S. A. 1965. Proliferative activity of blast cells in leukemia and myelofibrosis. Morphological differences between proliferating and nonproliferating blast cells. Acta Med. Scand. 178: 263.

41. Ming-Yu, C., and G. A. Fischer. 1968. Effects of cytosine arabinoside on the cell viability and uptake of deoxypyrimidine nucleosides in L5178Y cells. Biochem. Pharmacol. 17: 741 .

42. Winzler, R. J., A. D. Williams, and W. R. Best. 1957. Metabolism of human leukocytes in vitro. I. Effects of amethopterin on Formate- $C^{14}$ incorporation. Cancer Res. 17: 108

43. Kessel, D., T. C. Hall, and D. Roberts. 1968. Modes of uptake of methotrexate by normal and leukemic human leukocytes in vitro and their relation to drug response. Cancer Res. 28: 564.

44. Laszlo, J., J. Stengle, K. Wight, and D. Burk. 1958. Effects of chemotherapeutic agents on metabolism of human acute leukemia cells in vitro. Proc. Soc. Exp. Biol. Med. $97: 127$.

45. Smith, C. G., W. L. Lummis, and J. E. Grady. 1959. Improved tissue culture assay. II. Cytotoxicity studies with antibiotics, chemicals and solvents. Cancer Res. 19: 847.

46. Wright, J. C., J. P. Cobb, S. L. Gumport, D. Safadi, D. G. Walker, and F. M. Golomb. 1962. Further investigation of the relation between the clinical and tissue culture response to chemotherapeutic agents on human cancer. Cancer. 15: 284.

47. Watne, A. L., and J. A. DiPaolo. 1962. A correlation of clinical observations to in vitro sensitivity test for cancer chemotherapy. Cancer Chemother. Rep. 25: 109.

48. Bickis, I. J., I. W. D. Henderson, and J. H. Quastel. 1966. Biochemical studies of human tumours. II. In vitro estimation of individual tumour sensitivity to anticancer agents. Cancer. 19: 103.

49. Wolberg, W. 1964. Studies on the mechanism of human tumor resistance to the fluorinated pyrimidines. Cancer Res. $24: 1437$.

50. Scott, J. L., J. V. Marino, and E. P. Gabor. 1966. Human leukocyte metabolism in vitro. II. The effect of 6-mercaptopurine on formate- $\mathrm{C}^{14}$ incorporation into the nucleic acids of acute leukemic leukocytes. Blood. 28: 683 .
51. Cline, M. J. 1967. Prediction of in vivo cytotoxicity of chemotherapeutic agents by their effect on malignant leukocytes in vitro. Blood. 30: 176.

52. Oettgen, H. F., L. J. Old, E. A. Boyse, H. A. Campbell, E. S. Phillips, B. D. Clarkson, L. Tallal, R. D. Leeper, M. K. Schwartz, and J. H. Kim. 1967. Inhibition of leukemias in man by L-Asparaginase. Cancer Res. 27: 2619.

53. Riggs, D. S. 1963. The Mathematical Approach to Physiological Problems. The Williams \& Wilkins Company, Baltimore. 120.

54. Gallo, R. C., S. Perry, and T. R. Breitman. 1967. The enzymatic mechanisms for deoxythymidine synthesis in human leukocytes. J. Biol. Chem. 242: 5059.

55. Madoc-Jones, H., and W. R. Bruce. 1967. Comparison of the sensitivity of $\mathrm{L}$ cells in exponential and stationary phase to 5-fluorouracil. Nature (London). 215: 302.

56. Necheles, T. F., A. Maniatis, and D. M. Allen. 1968. Parameters of clinical response to methotrexate in acute leukemia. Clin. Res. 16: 310. (Abstr.)

57. Fallon, H. J., E. Frei III, and E. J. Freireich. 1962. Correlations of the biochemical and clinical effects of 6-azauridine in patients with leukemia. Amer. J. Med. Sci. 33: 526.

58. Ho, D. H., and E. Frei III. 1969. Clinical pharmacologic studies of L-asparaginase. Proc. Amer. Ass. Cancer Res. 10: 39 .

59. Kessel, D., T. C. Hall, D. Roberts, and I. Wodinsky. 1965. Uptake as a determinant of methotrexate response in mouse leukemias. Science (Washington). 150: 752.

60. Fischer, G. A. 1962. Defective transport of amethopterin (methotrexate) as a mechanism of resistance to the antimetabolite in L5178Y leukemic cells. Biochem. Pharmacol. $11: 1233$.

61. Roberts, D., and T. C. Hall. 1967. DHFR activity and deoxynucleoside incorporation into DNA of human leukocytes-relation to methotrexate administration. Cancer. 20: 905 .

62. Bertino, J. R., D. M. Donohue, B. Simmons, B. W. Gabrio, R. Silber, and F. M. Huennekens. 1963. The "induction" of dihydrofolic reductase activity in leukocytes and erythrocytes of patients treated with amethopterin. J. Clin. Invest. 42: 466.

63. Roberts, D., and T. Hall. 1967. The reduction of folate and dihydrofolate by homogenates of leukocytes from patients with leukemia or with myeloid metaplasia. Cancer Res. 27: 994.

64. Bertino, J. R., J. W. Hollingsworth, and A. R. Cashmore. 1963. Granulocyte kinetics in rheumatoid effusions studied by a biochemical label. Trans. Ass. Amer. Physicians Philadelphia. 76: 63.

65. Bertino, J. R., B. M. Simmons, and D. M. Donohue. 1961. Studies on the mechanism of resistance to the folic acid antagonists. Clin. Res. 9: 157. (Abstr.)

66. Hillcoat, B. L., V. Swett, and J. R. Bertino. 1967. Increase of dihydrofolate reductase activity in cultured mammalian cells after exposure to methotrexate. Proc. Nat. Acad. Sci. U. S. A. 58: 1632.

67. Rothenberg, S. P., C. Schreiber, and M. J. Clark. 1968. Mechanism of resistance to methotrexate by leukemic cells. Clin. Res. 16: 361. (Abstr.)

68. Bertino, J. R., R. Silber, M. Freeman, A. Alenty, M. Albrecht, B. W. Gabrio, and F. M. Huennekens. 1963. Studies on normal and leukemic leukocytes. IV. Tetrahydrofolate-dependent enzyme systems and dihydrofolate reductase. J. Clin. Invest. 42: 1899. 